Marquette University

e-Publications@Marquette

$1-1-2003$

\title{
Do Asymmetric Terms of Trade Shocks Affect Private Savings in a Transition Economy?
}

Abdur Chowdhury

Marquette University, abdur.chowdhury@marquette.edu

Published version.BOFIT Online, No. 3 (2003). Publisher Link.(C) 2003 BOFIT. Used with permission. 


\section{BOFIT personnel 2003}

\section{Economists}

Mr Pekka Sutela, head

Russian economy and economic policy

Russia's international economic relations

Baltic economies

Pekka.Sutela@bof.fi

Ms Tuuli Koivu, economist

Baltic economies

Tuuli.Koivu@bof.fi

Mr Tuomas Komulainen, economist

Russian financial system

Polish economy

Currency crises

Tuomas.Komulainen@bof.fi

Mr likka Korhonen, research supervisor

Baltic economies

Issues related to the EU enlargement

likka.Korhonen@bof.fi

Mr Vesa Korhonen, economist

Russia's international economic relations

Russia's banking system

Issues related to the EU enlargement

Vesa.Korhonen@bof.fi

\section{Information Services}

Mr Timo Harell, editor

Press monitoring

Timo.Harell@bof.fi

Ms Liisa Mannila, department secretary

Department coordinator

Publications traffic

Liisa.Mannila@bof.fi

\section{Contact us}

Bank of Finland

Institute for Economies inTransition, BOFIT

PO Box 160

FIN-00101 Helsinki
Ms Seija Lainela, economist

Russian economy and economic policy

Seija.Lainela@bof.fi

Mr Jouko Rautava, economist

Russian economy and economic policy

Jouko.Rautava@bof.fi

Mr Jian-Guang Shen, economist

Chinese economy and economic policy

Financial crises

Jian-Guang.Shen @bof.fi

Ms Laura Solanko, economist

Russian regional issues

Public economics

Laura.Solanko@bof.fi

Ms Merja Tekoniemi, economist Russian economy and economic policy Merja.Tekoniemi@bof.fi

Ms Päivi Määttä, information specialist Institute's library

Information services

Paivi.Maatta@ bof.fi

Ms Tiina Saajasto, information specialist

Statistical analysis

Statistical data bases

Internet sites

Tiina.Saajasto@bof.fi

Ms Liisa Sipola, information specialist Information retrieval

Institute's library and publications

Liisa.Sipola@bof.fi

Phone: $\quad$ +35891832268

Fax: $\quad+35891832294$

E-mail: bofit@bof.fi

Internet: www.bof.fi/bofit 


\section{BOFIT \\ Discussion Papers}

$2003 \cdot$ No. 3

Abdur R. Chowdhury

Do asymmetric terms of trade shocks affect private savings in a transition economy?

Bank of Finland Institute for Economies in Transition, BOFIT 
BOFIT Discussion Papers

Editor-in-Chief likka Korhonen

BOFIT Discussion Papers 3/2003

Abdur R. Chowdhury

Do asymmetric terms of trade shocks affect private savings in a transition economy?

ISBN 951-686-854-1 (print)

ISSN 1456-4564 (print)

ISBN 951-686-855-X (online)

ISSN 1456-5889 (online)

Suomen Pankin monistuskeskus

Helsinki 2003 


\section{Contents}

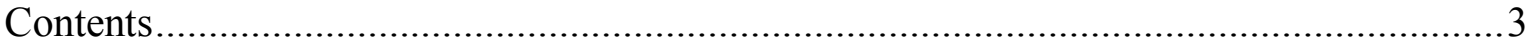

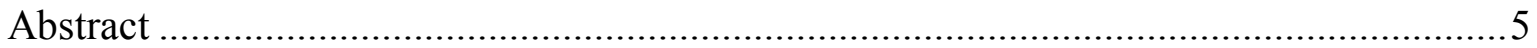

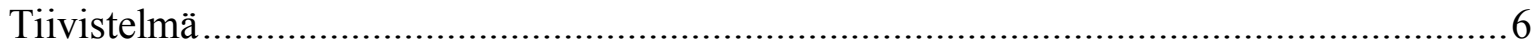

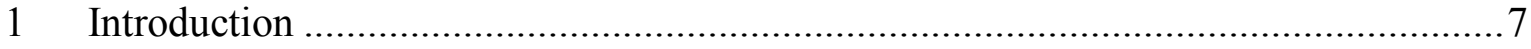

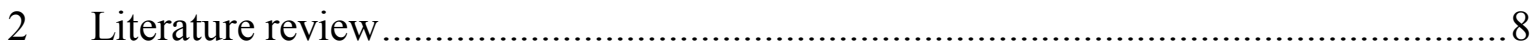

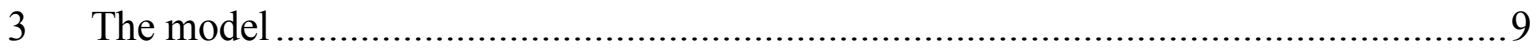

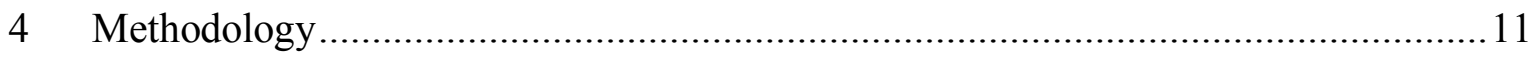

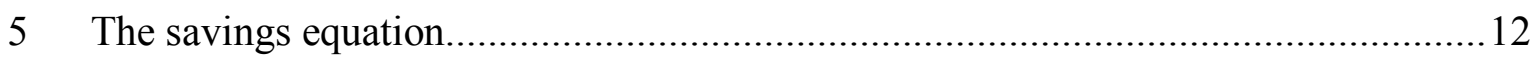

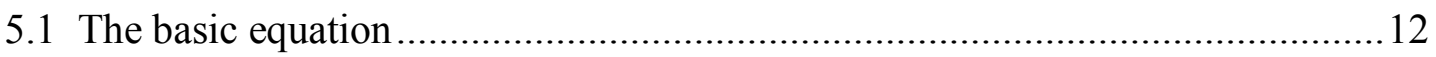

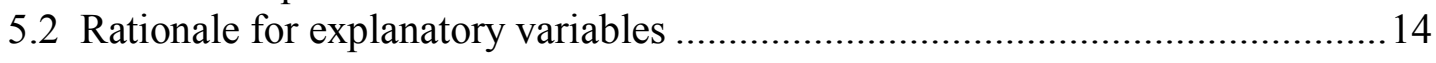

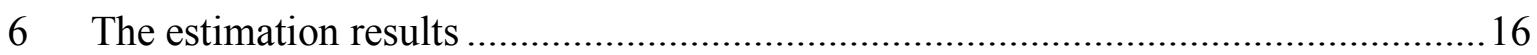

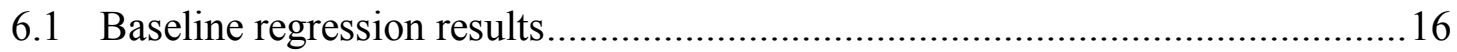

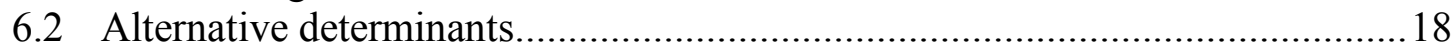

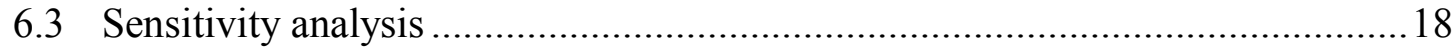

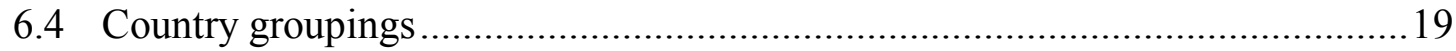

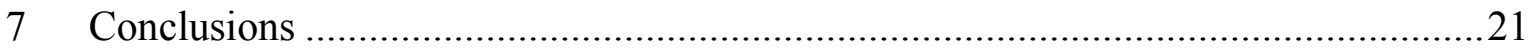

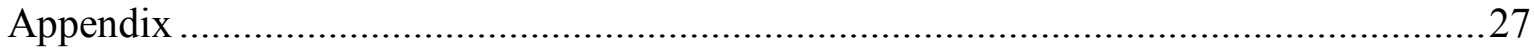

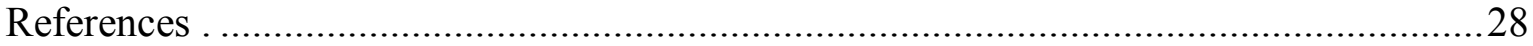


All opinions expressed are those of the author and do not necessarily reflect the views of the Bank of Finland. 


\title{
Abdur R. Chowdhury
}

\section{Do asymmetric terms of trade shocks affect private savings in a transition economy?}

\begin{abstract}
This paper examines whether terms of trade shocks have an asymmetric effect on private savings in transition economies. A simple three-period framework is developed to show that, in the presence of binding credit constraints in bad states of nature, savings rates can be sensitive to favorable movements in the permanent component of the terms of trade. This result contrasts with the prediction of the conventional consumption-smoothing model. Empirical analysis with a dynamic panel model further confirms that while favorable movements in the permanent component of the terms of trade have an asymmetric effect on private savings, the magnitude of the effect is relatively small. The results are robust for alternative estimators, determinants, and country groupings.
\end{abstract}

JEL classification: F10, E21, P33

Key words: transition, private savings, terms of trade

The author thanks Tuomas Komulainen, likka Korhonen, Jouko Rautava and other seminar participants at BOFIT for helpful comments on an earlier draft. The usual disclaimer applies. 
Abdur R. Chowdhury

\section{Do asymmetric terms of trade shocks affect private savings in a transition economy?}

\section{Tiivistelmä}

Tutkimuksessa käsitellään sitä, onko vaihtosuhdehäiriöillä epäsymmetrisiä vaikutuksia yksityisen sektorin säästämiseen siirtymätalouksissa. Yksinkertaisessa kolmen periodin mallissa todistetaan, että vaihtosuhteen pysyvän komponentin muutokset voivat vaikuttaa säästämisasteeseen, jos luottomarkkinat eivät toimi täydellisesti. Tämä tulos on ristiriidassa kulutuksen tasoittamisen tavanomaisten mallien kanssa. Dynaamisilla paneelimalleilla saadut empiiriset tulokset vahvistavat mallin tuloksen, vaikka epäsymmetrisen vaikutuksen koko ei ole suuri. Tulos ei muutu, vaikka käytettäisiin erilaisia estimaatteja, muuttujia tai maaryhmiä.

Asiasanat: transitio, yksityinen säästäminen, vaihtosuhde 
Terms of trade disturbances have been an important source of macroeconomic uncertainty in a number of transition economies [World Bank (1999)]. Many of these countries were heavily dependent on primary commodities that increased their vulnerability to external shocks and complicated macroeconomic management, particularly on the fiscal side (see Table 1a). Pressure on their current accounts was exacerbated by a sharp decline in commodity prices in the $1990 \mathrm{~s}$ and a continuous two-decade increase in the volatility of commodity prices (see Table $1 \mathrm{~b}$ ). ${ }^{1}$ Indeed, commodity prices are not only more volatile, they tend to be asymmetric with long troughs and sharp peaks, making it difficult to insulate a domestic economy from such shocks [Cashin et al (2002), Spatafora and Warner (1999)]..$^{2}$

A voluminous literature deals with the potential importance of terms of trade shocks in explaining macroeconomic performance. ${ }^{3}$ A question regularly raised in these studies is how economic agents should respond to greater fluctuations in tradable commodity prices and the resulting volatility in current account balances and real income. The theory of precautionary savings suggests that in response to an increase in the volatility of income arising, say, out of an increase in the likelihood of being unemployed, economic agents would increase their savings to hedge against a large negative income shock in the future. The international economics literature devotes particular attention to the response of private savings to terms of trade shocks in the context of macroeconomic models, where spending decisions are based on intertemporal optimization by forward-looking agents [Obstfeld (1982), Sachs (1981), Svensson and Razin (1983)]. This work generally finds that the nature of the impact of these shocks on private savings depends on whether the shocks are permanent or transitory, and expected or unexpected.

This paper focuses on the impact of asymmetric terms of trade shocks on private savings in transition economies. Almost all empirical studies in this area avoid the transition economies because their performance is less amenable to explanation with standard economic variables. This fact alone makes this study fairly novel in that it tackles this issue for the transition countries. We further choose a methodology that gives us a realistic expectation of obtaining results comparable in quality and reliability to those in the mainstream literature.

\footnotetext{
${ }^{1}$ Reinhart and Wickham (1994) show commodity prices have experienced a mostly secular decline along with an increase in volatility. The standard deviation for terms of trade growth has ranged from an average of 9 percent per year for developed countries to about 19 percent per year for developing countries [Baxter and Kouparitsas (2000)]. The World Bank's index of non-oil real commodity prices shows a trend decline of about 1.5 percent per annum since the late 1940s. The Bank further predicts this trend will continue over the next decade.

${ }^{2}$ Cashin et al (2002) found commodity price cycles asymmetric, i.e. price slumps lasted longer than price booms. Averaging across 36 real commodity price series, they estimated the typical length of price slumps (39 months) to be about 10 months longer than the typical length of price booms, giving an average cycle of about 68 months. Using a stock-holding model with intertemporal arbitrage, Deaton and Laroque (1992) identified the asymmetry involved in storage activity - stocks cannot be negative and a stock-out will lead to sharp price fluctuations - as the reason for this pattern of commodity price movements.

${ }^{3}$ Using cross-country growth regressions, Barro and Sala-i-Martin (1995) show that a change in the growth rate of terms of trade by 3.6 percentage points leads to a 0.4 percentage point change in the growth rate of real per capita GDP. Agenor et al (2000) found terms of trade disturbances to be highly correlated with output fluctuations.
} 
Savings in transition economies involve the shift from centralized investment to decentralized savings as the economic system moves from central planning to market principles. The absence of efficient credit and capital markets make private savings a key determinant of welfare in these economies. Without savings, households have few mechanisms to smooth unexpected changes in their income. Indeed, the capacity to save is crucial for increasing social mobility and raising future income-earning possibilities.

Most transition economies have witnessed a sharp decline in domestic savings rate. A striking feature of this decline has been the dramatic shift in the composition of savings toward households and away from corporate and general government. Given the growing importance of households in wealth accumulation in transition economies and the dearth of empirical research on the pervasiveness of resource constraints and the extent to which such constraints may be reducing growth prospects, we believe it is both timely and worthwhile to study those factors that may affect private savings. In this context, we specifically analyze the impact of terms of trade shocks on private savings after controlling for other determinants.

Empirical work on transition economies suffers from two obvious drawbacks. First, transition by definition involves a structural change in organization of an economy. Second, the available sample periods since the start of transition are relatively short. This fact has led many researchers of transition economies to opt for a panel approach that exploits the time-series dimension of the data rather than using only cross-sectional estimators. We apply the recently developed GMM dynamic panel data procedure that controls for simultaneity bias, bias induced by lagged dependent variables, and bias from omission of country-specific effects [Edison et al (2002)]. This approach, however, contains potential pitfalls [see Campos and Kinoshita (2002)]. Thus, we subject the basic results to sensitivity tests to check the robustness vis-à-vis alternative estimators, determinants, and country groupings.

The paper is organized as follows: Section II reviews the literature. The model is developed in Section III. The methodology is discussed in Section IV. Section V introduces the savings function. Empirical results and sensitivity test analyses are presented and discussed in Section VI. Concluding remarks are given in Section VII.

\section{$2 \quad$ Literature review}

The question "What is the impact of movements in the external terms of trade on private savings?" has been a source of a major debate in international economics for decades. The original response, known as the Harberger-Laursen-Metzler (HLM) effect [Harberger (1950), Laursen and Metzler (1950)], states that an improvement in the terms of trade increases a country's real income level, i.e. raises the purchasing power of a country's exports in the world market. For example, in a single-good static Keynesian open-economy model, assuming the marginal propensity to consume to be less than unity, private savings will increase. Similarly, deterioration in the terms of trade can be shown to lower private savings.

The research emphasis subsequently forked along "Dutch Disease" and "intertemporal choice" lines. The Dutch Disease literature builds on the tradable-nontradable dichotomy and concentrates on the sectoral impact of terms of trade shocks [see Corden (1984) for a detailed survey]. The intertemporal choice literature, which follows studies by Obstfeld (1982), Sachs (1981), and Svensson and Razin (1983), questions the theoretical basis of the 
HLM effect and argues that in two-good models (imports and exports) household saving decisions should be derived from solutions to a dynamic optimization problem of selecting consumption and savings at different points in time. These studies conclude that the relationship between terms of trade and savings is sensitive to the duration of terms of trade shocks. For instance, if improvements in the terms of trade are perceived to be permanent, economic agents will revise their estimate of national income upward for current and future periods. In sharp contrast to the HLM effect, a higher level of income leads to a higher level of consumption with no effect on savings. Correspondingly, if improvements are seen as temporary, economic agents will smooth this windfall gain over future periods by raising savings. Hence, the HLM effect holds only in the presence of transitory terms of trade shocks.

Dornbusch (1983) and Edwards (1989) question the view that transitory shocks to the terms of trade have an unambiguous impact on private savings. Using a three-good (imports, exports, non-tradables) model, these studies show that an adverse terms-of-trade shock can affect private savings in three ways. First, it will lower the current national income relative to future national income (consumption-smoothing or HLM effect). Second, it will increase the price of current imports relative to future imports, leading consumers to postpone their purchases and save more (consumption-tilting effect). Third, it will increase the price of imports relative to the price of the non-tradables, thereby leading to an appreciation of the real exchange rate. This ultimately increases the consumption rate of interest and provides an incentive to postpone current consumption and increase savings (real exchange rate effect). As pointed out by Cashin and McDermott (2002), in response to an adverse and transitory terms-of-trade shock, private savings will increase (decrease) if the consumption smoothing effect dominates (is weaker than) the saving-enhancing effects of the consumption-tilting and real exchange rate effects. ${ }^{4}$

Agenor and Aizenman (2002) suggest that terms of trade shocks may also lead to an asymmetric response in savings in developing countries. Slumps and booms in commodity prices trigger different responses to welfare changes. For example, households may be unable to smooth consumption when faced with adverse shocks to the terms of trade due to the presence of increased borrowing constraints in international financial markets. Consequently, economic agents may be forced to dissave by a larger amount than otherwise to maintain a smooth consumption path. To the extent that domestic agents internalize the possibility of facing restrictive borrowing constraints during hard times, they may also consume less and save more in good times.

The question of the sensitivity of private savings to terms of trade shocks is thus far from settled. Here, we analyze the relationship between these two variables in transition economies, a group of countries, as mentioned, omitted in most studies.

\footnotetext{
${ }^{4}$ Ogaki, Ostry, and Reinhart (1996) show that in low-income countries, where income levels are near subsistence, consumption-tilting and real exchange rate effects have a relatively limited impact on savings. Their results support the consumption-smoothing view of HLM, whereby transitory adverse disturbances in the terms of trade in poor countries tend to lower private savings.
} 


\section{The model}

Using an extended version of the model developed in Agenor and Aizenman (2002), we now present a basic model that incorporates the impact of asymmetric shocks in terms of trade on the savings decision. Consider a transition economy in trade relations with the rest of he world. Now assume a three-period model in which households are identical and survive for three periods. The total utility over the lifespan of a typical household, $\mathrm{H}$, is given by

$$
\mathrm{U}=\mathrm{h}\left(\mathrm{c}_{0}, \mathrm{c}_{1}\right)+\mathrm{h}\left(\mathrm{c}_{1}, \mathrm{c}_{2}\right)+\mathrm{h}\left(\mathrm{c}_{2}, \mathrm{c}_{3}\right),
$$

where

$$
h\left(c_{t-1}, c_{t}\right)=c_{t}-0.5 \alpha c^{2}-0.5 \beta\left(c_{t}-c_{t-1}\right){ }^{2}
$$

and where $\mathrm{c}_{\mathrm{t}}$ is consumption in period $t$ and $\alpha, \beta \geq 0$. $U$ is taken to be non-negative, strictly increasing in its arguments, strictly concave, and twice continuously differentiable. $\alpha$ is assumed to be so small that the marginal utility of consumption in the relevant region is greater than zero. Equation (2) permits the formation of habit, i.e. changes in the current level of consumption relative to the previous level leads to disutility proportional to $\beta$. For simplicity, it is assumed that both income and consumption remain stable over the life of the model. Hence, the initial level of assets in period 1 is zero and consumption is equal to income:

$$
\mathrm{y}_{0}=\mathrm{c}_{0}=1,
$$

where $y$ is income. Now consider the effect of a change in the underlying stochastic process of income at the beginning of period 1. First, a permanent shock increases income by $\varepsilon$. Second, an adverse transitory shock due, say, to an adverse change in the terms of trade, may occur in the second period with probability $p$, lowering second-period income by $\delta$. Consequently, the new income path is expected to be

$$
\begin{aligned}
& y=y_{t}=1+\varepsilon, \quad t=1,2,3 \quad \text { with probability (1-p) } \\
& =y_{1}=y_{3}=1+\varepsilon, \quad y_{2}=1+\varepsilon-\delta \text { with probability } p
\end{aligned}
$$

In the absence of habit formation (i.e. $\beta=0$ ) and with a mature capital market, the model described by equations (1) and (2) represents a consumer who behaves according to the permanent income hypothesis. In other words, in the presence of an adverse transitory shock in period 2, this consumer will borrow in the second period from the capital market to smooth his consumption path.

Such a scenario may not be applicable for a transition economy where capital markets function poorly and consumers are unable to borrow due to such factors as credit constraints or lack of access to international capital markets due to high sovereign risk. Under these circumstances, the maximization problem of the representative household becomes: $:^{5}$

\footnotetext{
${ }^{5}$ We assume the transitory shock is greater than both the habit formation parameter, $\beta$, and the permanent shock.
} 


$$
\begin{array}{ll}
\operatorname{Max}_{\mathrm{s}_{1}, \mathrm{~s}_{2}} & \mathrm{~h}\left(1 ; \mathrm{x}-\mathrm{s}_{1}\right)+ \\
& \mathrm{p}\left[\mathrm{h}\left(\mathrm{x}-\mathrm{s}_{1} ; \mathrm{x}-\delta+\mathrm{s}_{1}\right)+\mathrm{h}\left(\mathrm{x}-\delta+\mathrm{s}_{1} ; \mathrm{x}\right)\right]+ \\
& (1-\mathrm{p})\left[\mathrm{h}\left(\mathrm{x}-\mathrm{s}_{1} ; \mathrm{x}+\mathrm{s}_{1}-\mathrm{s}_{2}{ }_{2}\right)+\mathrm{h}\left(\mathrm{x}+\mathrm{s}_{1}-\mathrm{s}_{2}{ }_{2} ; \mathrm{x}+\mathrm{s}^{\mathrm{H}_{2}}\right)\right],
\end{array}
$$

where $x=1+\varepsilon$, and $s_{2}{ }_{2}$ denotes second period savings if the adverse income shock is zero.

The first-order condition for equation (4) provide two linear equations in $s_{1}$ and $s_{2}{ }_{2}$, from which we derive the following equation for first-period savings:

$$
\mathrm{S}_{1}=[\{\delta \mathrm{p}(1+3 \theta)+\varepsilon \theta\}(2+5 \theta)] /\left[(2+6 \theta)(2+5 \theta)-(1-\mathrm{p})(1+4 \theta)^{2}\right]
$$

where $\theta=\beta / \alpha^{6}$

Here, the transitory shock to second-period income can be interpreted as a temporary terms of trade shock. In the spirit of the symmetric Harberger-Laursen-Meltzer consumptionsmoothing framework, the model predicts that positive (negative) transitory income shocks are entirely saved (dissaved). Moreover, in the presence of habit formation, a fraction of permanent income would be set aside during good times, i.e. in period 1. Following Agenor and Aizenman (2002), it can be shown that in equation (5), the permanent shock, $\varepsilon$, positively influences first-period savings. Thus, the possibility of credit constraints in bad states of nature, e.g. an adverse terms-of-trade shock, leads to an asymmetric response of savings to permanent income shocks. ${ }^{7}$

The model can be extended to show that under asymmetric utility preferences representing loss aversion, where individuals exhibit a larger degree of risk aversion to adverse shocks to income, they tend to save more in good times, increasing their consumption by less than the increase in income. ${ }^{8}$ Under this scenario, loss-averse consumers tend to treat the future asymmetrically, assigning a greater probability weight to bad states of nature in measuring expected utility. This gives rise to an asymmetric response of savings relative to the conventional expected utility framework.

\footnotetext{
${ }^{6}$ Agenor and Aizenman (2002) show that, in the absence of habit formation (since $\beta=0$, so $\theta=0$ ), equation (5) can be written as $\mathrm{S}_{1}=\delta \mathrm{p} /[2-0.5(1-\mathrm{p})]$. Thus, compared to a situation with no credit constraint, firstperiod savings will be higher when binding constraints are present. The greater the probability of an adverse shock to second-period income and larger the magnitude of the shock, the greater the gap between the savings rates with and without credit constraints.

${ }^{7}$ To conserve space, only the case of an adverse transitory shock in the second period is illustrated in this paper. For the effect of a positive transitory second-period shock, see Agenor et al (2000).

${ }^{8}$ See Aizenman (1998).
} 


\section{$4 \quad$ Methodology}

Three issues need to be considered in selecting an estimation procedure. First, we want to allow for inertia in savings ratio that may arise from lagged effects of the explanatory variables on savings. ${ }^{9}$ Second, some regressors included in the equation such as real income growth and public savings may be jointly endogenous, i.e. correlated with the error term. Third, unobserved time- and country-specific factors may be correlated with the explanatory variables producing biased and inconsistent estimates.

To address these issues, our empirical strategy is based on a recently developed dynamic panel data technique. The generalized method of moments (GMM) technique, initially proposed in Hansen (1982) and later refined in Arellano and Bover (1995) and Blundell and Bond (1998) is used here for estimating a set of moment conditions to generate consistent and efficient estimators. ${ }^{10}$ The GMM estimator combines into a single system the regression equation in both changes and levels, each with its specific set of instrumental variables.

The methodology is briefly described in this section. Let the dynamic reduced-form savings regression equation be:

$$
\mathrm{y}_{\mathrm{i}, \mathrm{t}}=\beta_{1} \mathrm{y}_{\mathrm{i}, \mathrm{t}-1}+\beta_{2} \mathrm{X}_{\mathrm{i}, \mathrm{t}}+\eta_{\mathrm{i}}+\varphi_{\mathrm{i}, \mathrm{t}}
$$

where $y$ is the savings rate, $X$ represents a set of variables that potentially affect the savings rate and for which time and cross-sectional data are available, $\eta$ represents a set of unobserved time-invariant country specific effects, and $\varphi$ is the error term. Specifying the regression equation in difference form helps eliminate the country-specific effect and allows lagged levels of endogenous variables become valid instruments [Anderson and Hsiao (1982)]. Thus:

$$
\mathrm{y}_{\mathrm{i}, \mathrm{t}}-\mathrm{y}_{\mathrm{i}, \mathrm{t}-1}=\beta_{1}\left(\mathrm{y}_{\mathrm{i}, \mathrm{t}-1}-\mathrm{y}_{\mathrm{i}, \mathrm{t}-2}\right)+\beta_{2}\left(\mathrm{X}_{\mathrm{i}, \mathrm{t}}-\mathrm{X}_{\mathrm{i}, \mathrm{t}-1}\right)+\left(\varphi_{\mathrm{i}, \mathrm{t}}-\varphi_{\mathrm{i}, \mathrm{t}-1}\right) .
$$

The first issue raised is the likely endogeneity of the explanatory variables, $X$, shown by the correlation between these variables and the error term. A second issue is the correlation of the error term in equation (7) with the differenced lagged dependent variable in the same equation. We control for joint endogeneity using instruments based on lagged values of the explanatory variables. Thus, instead of assuming that the explanatory variables be uncorrelated with the error term at all leads and lags (strict exogeneity), weak exogeneity is assumed. This allows for the possibility of simultaneity and reverse causation. Thus, current explanatory variables may be affected by past and current realizations of the dependent variable, but not by its future innovations [see Calderon et al (2001) and Loayza et al (1999)]. Under these assumptions, the following set of moment conditions are formulated and applied to the lagged savings rate and the set of regressors:

$$
\begin{array}{ll}
E\left[y_{i, t-k}\left(\varphi_{i, t}-\varphi_{i, t-1}\right)\right]=0 & \text { for } k \geq 2, t=3, \ldots T \\
E\left[X_{i, t-k}\left(\varphi_{i, t}-\varphi_{i, t-1}\right)\right]=0 & \text { for } k \geq 2, t=3, \ldots T
\end{array}
$$

\footnotetext{
${ }^{9}$ This dynamic specification helps differentiate between short- and long-run effects on savings [See Loyza et al (1999)].

${ }^{10}$ Studies using this method include Calderon et al (1999, 2001), Edison et al (2002), Fajnzylber et al (1998), Konings et al (2002), and Loayza et al (1999).
} 
The GMM estimator based on equations (8) and (9) is known as the "difference estimator" [Calderon et al (1999)]. Despite being asymptotically consistent, this estimator has low asymptotic precision and large biases in small samples [Blundell and Bond (1998)]. ${ }^{11}$ To mitigate this concern, the estimator presented in Arellano and Bover (1995) is used. This estimator combines, in a system, regression equation in levels with the regression in differences. Unlike the difference regression, where country-specific effects are eliminated, the regression in levels only controls for the use of such effects through instrumental variables.

The instruments for the regression in differences are the lagged levels of the corresponding variables. Therefore, the moment conditions in equations (8) and (9) apply for the first panel of the system. For the second part, the appropriate instruments for the regression in levels are the lagged differences of the corresponding variables. The additional moment conditions for the regression in levels are given by: ${ }^{12}$

$$
\begin{array}{lr}
E\left[\left(y_{i, t-k}-y_{t-k-1}\right)\left(\eta_{i}+\varphi_{i, t}\right)\right]=0 & \text { for } k=1 \\
E\left[\left(X_{i, t-k}-X_{i, t-k-1}\right)\left(\eta_{i}+\varphi_{i, t}\right)\right]=0 & \text { or } k=1 .
\end{array}
$$

Following Arellano and Bond (1991) and Arellano and Bover (1995) and using the moment conditions given in equations (8)-(11), we employ the GMM technique to generate consistent estimates of the parameters.

The consistency of the estimator depends on whether the lagged values of the explanatory variables are valid instruments in the regression equation. We investigate this using two specification tests given in Arellano and Bond (1991) and Arellano and Bover (1995). ${ }^{13}$ The first is the Sargan test of overidentifying restrictions. It tests the overall validity of the instruments by analyzing the sample analog of the moment conditions used in the estimation process. The null hypothesis is that the instruments are not correlated with the residuals in the first-difference regressions. ${ }^{14} \mathrm{~A}$ non-rejection of the null hypothesis provides support to the model. ${ }^{15}$ The second specification test refers to the hypothesis that the error term is not serially correlated. In particular, we test for the order of serial correlation for the residual of the regression in differences. As a first-order serial correlation is expected, we test the null hypothesis of absence of second-order serial correlation. Failure to reject the null hypothesis shows the original error term is serially uncorrelated.

\footnotetext{
${ }^{11}$ The construction of the difference estimator eliminates the cross-country relationship between the savings rate and the regressors. Blundell and Bond (1998) have shown that, in the presence of persistence of the regressors over time, the lagged levels of these variables are weak instruments for the regression equation in differences. This leads to an increase in asymptotic inefficiency and small sample bias of the difference estimator.

${ }^{12}$ For a description of the assumptions under which these moment conditions hold, see Loayza et al (1999).

${ }^{13}$ For a simple description of these tests, see Calderon et al (2001). These two tests are also used in Fajnzylber et al (1998) and Loayza et al (1999).

${ }^{14}$ Under the null hypothesis, the asymptotic distribution of the test statistic is chi-square with $(m-q)$ degrees of freedom, where $m$ is the number of instruments and $k$ is the number of explanatory variables.

${ }^{15}$ Bowsher (2002) has recently argued that the excessive use of moment conditions in moderately large time series dimensions can cause the Sargan test to be undersized and have extremely low power. Interestingly, Bowsher found the alternative Exponential Tilting Parameter test generally possessed worse size properties than the conventional Sargan test. This criticism of the Sargan test is likely inapplicable here as our time series is relatively small.
} 


\section{$5 \quad$ The savings equation}

\subsection{The basic equation}

Based on the literature, we derive an empirical savings function that includes a broad range of savings determinants. ${ }^{16}$ Specifically, in the basic equation, the per capita savings rate (PS) is modeled as a function of the one-period lagged per capita savings rate [PS(-1)], real per capita income (RPCY), real per capita GDP growth (GRPCY), level of monetization (M2/GDP), inflation rate (INF), the ratio of public savings to gross national disposable income (PUBSAV), dependency ratio (DEP) and four variables relating to the terms of trade (PTOT, TTOT, VTOT, DUMMY), so that:

$\mathrm{PS}_{\mathrm{t}}=\alpha_{0}+\alpha_{1} \mathrm{PS}_{\mathrm{i}, \mathrm{t}-1}+\alpha_{2} \mathrm{RPCY}_{\mathrm{it}}+\alpha_{3} \mathrm{GRPCY}_{\mathrm{it}}+\alpha_{4} \mathrm{M} 2 / \mathrm{GDP}_{\mathrm{it}}+\alpha_{5} \mathrm{INF}_{\mathrm{it}}+\alpha_{6} \mathrm{PUBSAV}_{\mathrm{it}}+$ $\alpha_{7} \mathrm{DEP}_{\text {it }}+\alpha_{8} \mathrm{PTOT}_{\text {it }}+\alpha_{9} \mathrm{TTOT}_{\text {it }}+\alpha_{10} \mathrm{VTOT}_{\text {it }}+\alpha_{11} \mathrm{DUMMY}$

\subsection{Rationale for explanatory variables}

The lagged private savings rate $\left(\mathrm{PS}_{\mathrm{t}-1}\right)$ can be an important predictor of the current savings rate as it captures habit-formation effects and measures the rate of partial adjustment of the desired savings propensity to its actual value. ${ }^{17}$ The inclusion of real per capita income (RPCY) is fairly standard in the savings literature [Dayal-Gulati and Thimann (1997), Kent (1997), Lahiri (1989)]. However, the impact of income on savings has been inconclusive in theoretical models. The simple permanent income theory predicts higher economic growth reduces private savings. In contrast, intertemporal optimizing models such as the life-cycle model suggest a positive relationship between national income and private savings. Most of the cross-country empirical studies find that a permanent increase in income has a positive effect on the private savings rate. ${ }^{18}$

The growth rate of GDP (GRPCY) captures improvements in the standard of living and should have a positive impact on savings. The level of monetization (M2/GDP) is measured by the share of broad money in GDP. This is a realistic proxy for financial development and reform in transition economies; those countries that have made the most progress in reforming their financial systems in terms of rehabilitation and privatization of the banking system, establishing and enforcing prudential banking regulations, and establishing functioning capital market are also among those with the highest monetization ratios [UN (2001)]. The sign of this variable is ambiguous. As far as it represents the development of the financial system in the country, it should have a positive effect on savings. Zeldes (1989) argues that the monetization variable should have a negative sign as

\footnotetext{
${ }^{16}$ Loayza et al (1999) provides an excellent summary of various determinants of savings and findings from previous empirical studies.

${ }^{17}$ Alessie and Lusardi (1997) consider models of habit formation and show that savings depend not only on future income changes and income risk, but also on past saving. There is also an econometric argument for including this variable; the error process in a dynamic specification suffers from a potential problem of serial correlation. This has important implications for both the validity test of the instruments used in the estimation process, as well as its impact on consistency of the estimates. To specify a dynamic regression with uncorrelated disturbances, the lagged value of savings should be included as an additional control.

${ }^{18}$ See e.g. Blanchard and Fischer (1989) and Bosworth (1993).
} 
it captures the borrowing constraints faced by the consumers and leads to lower savings through better possibilities to finance consumption.

The inflation (INF) variable, measured as the annual percentage change in the CPI, should have a negative impact on the savings rate as it reflects precautionary savings effect due to macroeconomic instability and income variability [Fischer (1993)].

Fiscal policy can potentially affect private savings through revenue policy (e.g. tax structure), expenditure policy (e.g. income distribution), or the extent of public savings. Our goal here is to find out the extent to which the private sector in transition countries internalize the government budget constraint, and hence, the extent to which an increase in public savings is offset by increased private savings. Hence, a public savings variable (PUBSAV) that measures budget surplus as a percent of GDP is included.

The dependency ratio (DEP) captures the life-cycle effect and is included to measure the impact of demographic variables on the savings rate. As aggregate data on private savings include both savings by the working population and dissaving by the retired, demographic changes with respect to the relative size of these two groups could also offset private savings. The variable (DEP) is defined as the share of non-active population in total population.

Next, a set of variables measuring the possible impact of terms of trade shocks is included in the model. Terms of trade is computed as the ratio of merchandise exports deflator to the merchandise imports deflator with 1995 as the base year. The permanent component of the terms of trade (PTOT) is estimated by the trend series obtained from a standard Hodrick-Prescott (HP) filter. ${ }^{19}$ Following Agenor and Aizenman (2002), the measure is weighted by the ratio of exports to GDP to capture the fact that the higher the share of exports in output, the higher the impact of volatility on the terms of trade. The transitory component of the log of the terms of trade (TTOT) is the filtered series obtained from the use of the HP filter. This variable is weighted by the ratio of exports to GDP and anticipated to have a positive impact on savings. A time-varying measure of terms of trade volatility (VTOT) is included as a proxy for income uncertainty, ${ }^{20}$ which is expected to have a negative impact on savings.

The presence of an asymmetric effect of terms of trade on saving is captured by a dummy variable (DUMMY). Following Agenor and Aizenman (2002), the variable is an interactive dummy that takes the value of unity times the logarithm of the permanent

\footnotetext{
${ }^{19}$ The HP filtering technique can be described as follows: Let a seasonally adjusted variable, $\mathrm{y}_{\mathrm{t}}$ be written as the sum of an unobserved trend component, $\mathrm{y}_{\mathrm{t}}{ }_{\mathrm{t}}$, and a residual cyclical component, $\mathrm{y}_{\mathrm{t}}^{\mathrm{r}}$. The HP filter uses an adjustment method where the trend component moves continuously and adjusts gradually. The trend component is selected by minimizing the sum of the squared deviations from the observed series, subject to the constraint that changes in $\mathrm{y}_{\mathrm{t}}{ }_{\text {vary }}$ gradually over time. Thus,

$$
\begin{aligned}
& \mathrm{T} \quad \mathrm{T}-1 \\
& \operatorname{Min} \sum\left(\mathrm{y}_{\mathrm{t}}-\mathrm{y}_{\mathrm{t}}\right)^{2}+\lambda \sum\left[\left(\mathrm{y}_{\mathrm{t}+1}^{*}-\mathrm{y}_{\mathrm{t}}^{*}\right)-\left(\mathrm{y}_{\mathrm{t}}{ }_{\mathrm{t}}-\mathrm{y}_{\mathrm{t}-1}{ }^{*}\right)\right]^{2} \text {. } \\
& \mathrm{t}=1 \quad \mathrm{t}=2
\end{aligned}
$$

The Lagrange multiplier, $\lambda$, is the smoothing component such that higher values of $\lambda$ lead to a smoother trend series. The use of the HP filter here has been criticized on the grounds that it removes potentially valuable information from the time series [King and Rebelo (1993)].

${ }^{20}$ Following the method discussed in Chowdhury (1993), the variable is constructed by the moving sample standard deviation of the growth rate of the terms of trade:

$$
\mathrm{k}
$$

$\mathrm{V}_{\mathrm{t}}=\left[(1 / \mathrm{k}) \sum\left(\log \mathrm{Q}_{\mathrm{t}+\mathrm{i}-1}-\log \mathrm{Q}_{\mathrm{t}+\mathrm{i}-2}\right)^{2}\right]^{1 / 2}$,

where $k=3$ is the order of the moving average. Estimations using $k=2$ have also been performed. The conclusion appears robust irrespective of the value of $k$. 
component of the terms of trade weighted by the ratio of exports to GDP when that component increases above its previous value. Otherwise, it is given a value of zero.

In addition to the basic set of regressors included in equation (12), estimations are performed using alternative determinants of savings. Specifically, four variables are selected. VTOT is replaced by an alternative measure of income uncertainty (VINC) as represented by the moving sample standard deviation of the growth rate of per capita real income. This variable is expected to have a positive impact on the savings rate. Foreign savings $(\mathrm{CAB})$ is measured by the ratio of current account balance to GDP. A cuurent account deficit (negative sign) for this variable refers to the net amount of foreign savings that have been attracted in addition to domestic savings. A surplus (positive sign) suggests substitutability of the two variables. ${ }^{21}$

Two price variables representing the financial market are used. First, the real interest rate (RINT) is measured as the difference between the one-year time deposit rate and the expected rate of inflation. To overcome the problem of unobservable expected inflation rate, it is assumed that expectations are formed according to the adaptive expectation model:

$$
p_{t}^{e}-p_{t-1}^{e}=b\left(p_{t}^{e}-p_{t-1}^{e}\right)
$$

where $b$ is the coefficient of expectations such that $0<b<1$.

Second, following Koivu (2002), the difference between the lending and deposit rates in banking sector (MARGIN) is used as an estimator of banking efficiency. Koivu shows that a decrease in this rate differential due to a fall in the transaction costs leads to a higher share of savings going to investment, thereby accelerating economic growth.

\section{$6 \quad$ The estimation results}

\subsection{Baseline regression results}

Estimations have been performed using annual unbalanced panel data for 21 countries in Eastern Europe and the former Soviet Union for the 1993-2001 sample period. ${ }^{22}$ Data on the private and public savings rate have been taken from the Economic Survey of Europe published by the United Nations Economic Commission for Europe. Data on all the other variables are taken from various issues of the Transition Report published by the European Bank for Reconstruction and Development and International Financial Statistics published by the International Monetary Fund.

Table 2 reports the results of the regression equations for private savings using alternative estimators on the full sample and the basic specification. To facilitate comparison with the GMM dynamic panel technique, estimates using cross-section data

\footnotetext{
${ }^{21}$ A foreign savings variable has been included in a number of studies [Edwards (1996), Loayza et al (1999), and Masson et al (1998)], while excluded in others [e.g. Agenor and Aizenman (2002)].

${ }^{22}$ Countries in the sample include Bulgaria, Croatia, the Czech Republic, Hungary, Poland, Romania, Slovakia, Slovenia, Macedonia, Estonia, Latvia, and Lithuania from the Eastern Europe and Baltic States category. FSU countries include Armenia, Azerbaijan, Belarus, Georgia, Kazakhstan, Moldova, the Russian Federation, Ukraine, and Uzbekistan. Availability of data constrained the choice of countries, sample period, and variables.

To minimize balance problems, countries included in the sample have at least five observations. We started with 168 observations. Since three observations per country were used for constructing the instruments, the basic regression sample consists of 105 observations.
} 
(column 1) and pooled annual data in static specification without the lagged savings rate (column 2) are presented. Neither specification deals with endogeneity and unobserved country-specific effects. In both cases, the rejection of the null hypothesis for both the error serial correlation tests indicate that the estimated coefficient in these specifications cannot offer valid conclusions as relevant variables with high over-time persistence are not included.

The third regression shown in column 3 is the basic dynamic specification, which includes the lagged savings term. Consistent with our previous discussion, note that the panel estimates, by construction, exhibit first-order serial correlation. However, our primary concern is the presence of second-order serial correlation. Both the hypotheses of lack of second-order residual serial correlation and of no correlation between the error term and the instruments (Sargan test) cannot be rejected. This supports the dynamic specification, as well as the instruments used in the estimation process. Results from the Wald test show that the coefficients are jointly significant.

The coefficient on the lagged private savings rate is, as expected, positive. The value of 0.529 shows the presence of a large degree of persistence. Indeed, the view that past savings is an important predictor of current savings in the transition economies appear to be confirmed. This also implies that, if all changes in any of the explanatory variables are permanent, the long-run effect is exactly 2.12 times higher than the short-run effect. The positive and statistically significant coefficient on the per-capita income variable implies that countries with higher per capita income tend to save relatively more than countries with lower per capita income. Confirming the theoretical relationship shown in an intertemporal model (e.g. life-cycle hypothesis), this may help explain why savings have been higher in the Eastern European countries and the Baltic states relative to other former Soviet Union states. The business cycle effect, measured by the coefficient on the GDP growth rate, holding the per capita income constant, is statistically insignificant.

The financial depth variable (measured by the ratio of M2 to GDP) has a highly significant negative impact on private savings. When the volume of M2 rises by 1 percent of GDP, the private savings rate decreases by 0.24 percentage point. This result confirms the widely held view that financial reforms may stimulate consumption by relaxing domestic liquidity constraints e.g. through increased access to bank credit, and thus reduce the propensity to save. Similar results have been reported for Sub-Saharan Africa [Agenor and Aizenman (2002)], and 69 developed and developing countries [Loayza et al (1999)]. ${ }^{23}$ Inflation has a positive impact on savings. An increase of inflation by 10 percentage points raises private savings by eight-tenths of one percentage point. The results indicate that increased uncertainty about the aggregate economy and expectations of further price increases induce agents to lower their current consumption and increase precautionary savings.

The coefficient on public savings is negative and statistically significant, which suggests that the private sector internalize the government's budget constraint. The shortterm coefficient is 0.176 giving a permanent long-term value of 0.373 . Since the coefficient is statistically less than one, we can reject Ricardian equivalence for the full sample.

The dependency ratio variable has the expected negative sign, but is marginally significant in the equation. This result is consistent with the basic life-cycle models of consumption, indicating a positive relationship between the private savings rate and the share of working-age people in the total population.

\footnotetext{
${ }^{23}$ Chowdhury (2001) and Jappelli and Pagano (1995) also report a negative relationship between financial reform and private savings in the developing countries.
} 
Next, we consider the variables of interest for this study. Both the permanent and temporary components of the terms of trade are positive and statistically significant. This is similar to the results reported for a group of developing countries in Masson et al (1998) and both developed and developing countries in Loayza et al (1999). Moreover, the magnitude of the coefficient on the temporary component is much larger than that of the permanent component. This reflects the lack of access to foreign borrowing that many transition economies faced during the 1990s. The short-term coefficient on the transitory variable is 0.274 , so the long-term effect is around 0.582 . As both values are significantly less than one, there is an incomplete pass-through in the system. This may be due to the inability of the households to fully judge the persistence of the terms of trade shock at the moment it occurs. Agenor and Aizenman (2002) report similar findings for Africa.

The volatility of the terms of trade has a statistically significant negative impact on savings. This contradicts the findings reported in Agenor and Aizenman (2002). The dummy variable has the anticipated positive sign, but is small in magnitude. This suggests that, despite evidence of the asymmetric impact of terms of trade shocks, the size of the impact is relatively small in transition economies.

\subsection{Alternative determinants}

In this subsection, the basic savings equation (12) is extended by including an augmented set of explanatory variables. The obvious candidates for this group include those that are explicitly implied by economic theory and used in empirical studies.

The potential determinants are each added separately to the basic equation given in Table 2 (column 3). The results are reported in Table 3. In the first equation (column 1), a proxy for income uncertainty (VINC), measured as the moving sample standard deviation of per capita GDP growth, is added. The estimated coefficient has the positive sign as is expected from the precautionary saving motive and is significant. This provides evidence that in response to an increase in the volatility of income, due e.g. to an increase in the likelihood of being unemployed, an economic agent will increase his private savings to hedge against the greater probability of a large negative income shock in the future. In the presence of the income volatility variable, the inflation variable loses some of its significance, which indicates that the income variable captures some of the inflationary effects of macroeconomic uncertainty.

In the second equation (column 2) add the current account deficit. The coefficient is positive indicating that a decrease in the current account balance (or an increase in foreign savings) is partly balanced by a fall in private savings. The short-term coefficient is 0.292 , while the long-term effect is 0.582 showing that in the long run a 1 percent increase in foreign savings as a proportion of GDP would lead to approximately a sixth-tenth of one percent decline in the savings rate. The next variable added to the basic equation is the real interest rate (column 3). The coefficient is negative but statistically insignificant. ${ }^{24}$ This means that the positive substitution effect of an increase in real interest rate is cancelled out by the negative income effect. Further analysis shows that the real interest rate variable is highly correlated with the inflation rate with a correlation coefficient of 0.65 . This implies that during the sample period considered, nominal rates adjusted rather slowly to

\footnotetext{
${ }^{24}$ Ogaki et al (1996) and Elbadawi and Mwenga (1999) also found private savings to be insensitive to changes in real interest rates in a number of low- and middle-income developing countries.
} 
changes in economic fundamentals and that, on average, changes in inflation dominated the movements in real interest rates. ${ }^{25}$

The fourth variable, interest margin, is a proxy for banking efficiency in these countries. The coefficient has a positive sign and is statistically significant confirming the economic implications discussed in Koivu (2002). Financial reform has improved banking efficiency. This raised conspicuous consumption, and thereby lowered private savings.

The value of the lagged savings rate varies between 0.498 and 0.537 in the four equations. The degree of persistence remains strong in the presence of additional regressors. The values for the other explanatory variables in the table are qualitatively similar to those found in the basic regression equation in Table 2.

\subsection{Sensitivity analysis}

As transition countries have experienced wide variations growth, the robustness of the results to regional coverage is investigated. First, the basic model is reestimated, removing one country at a time. This process ensures that any undue effects of an outlier country will be reflected by significantly different results for the sample omitting that country. Although the coefficient estimates (not reported here) vary slightly, there is no qualitative change in the results.

Next, we investigate the relationship between various significant measures of terms of trade shocks and the savings rate to determine if they are robust or sensitive to small changes in the conditioning information set. The reliability and robustness of the relationship are evaluated using a version of Leamer's (1983) extreme bounds analysis as developed in Levine and Renelt (1992).26 In particular, the following regression is estimated:

$$
\mathrm{PS}=\mathrm{a}+\mathrm{b}_{\mathrm{i}} \mathbf{I}+\mathrm{c}_{\mathrm{z}} \mathbf{Z}+\mathrm{u},
$$

where $P S$ is the savings rate, $\boldsymbol{I}$ is the set of base variables of interest included in all regressions and $\boldsymbol{Z}$ is a subset of variables selected from a pool of potentially important explanatory variables of savings. We first run a base regression that includes only the $\boldsymbol{I}$ variables. Then we compute the regression results for all possible linear combinations of up to three $\boldsymbol{Z}$ variables and identify the lowest and highest values for the coefficients in the $\boldsymbol{I}$ vectors of variables that cannot be rejected at the 5-percent level of significance. If the estimated coefficients remain significant over this procedure, the correlation is said to be "robust." The extreme bound is the highest estimated correlation plus two standard errors and the lowest minus two standard errors. If the coefficient fails to be significant in some regression, the correlation is termed "fragile."

Four variables earlier found to be statistically significant are included in the $\boldsymbol{I}$ vector TTOT, PTOT, VTOT, and PS(-1). The pool from which the set of three control variables $\boldsymbol{Z}$ is drawn includes all the remaining ten explanatory variables used in Tables 1 and 2 . During estimation, we select three variables from the pool of ten variables each time, adding these three variables to the base regression of four variables, to see whether the

\footnotetext{
${ }^{25}$ In addition to government controls, the rigidity in nominal interest rates is due to factors that include the oligopolistic nature of the domestic banking system, inadequate banking supervision, and relatively thin domestic money, credit, and capital markets.

${ }^{26}$ See Chowdhury (2001) and the references therein for an application of this procedure. Radulescu and Barlow (2002) employed the extreme bound analysis for a group of transition economies.
} 
parameters in the base regression are stable. The extreme bound results are given in Table 4. The GMM system estimator results appear to be robust. The four key variables keep the right sign, remain significant, and have values for the estimated coefficient that are consistent with those reported in the paper. For PS(-1), PTOT, TTOT, and VTOT the ranges are $(0.575,0.662),(0.041,0.092),(0.095,0.206)$, and $(0.194,0.296)$, respectively. In summary, the coefficient estimates are fairly stable and insensitive to various extra regressors.

\subsection{Country groupings}

Given the differences in institutional characteristics and macroeconomic performance during the transition process, we then reestimate the model separately for three groups the countries set join the European Union (EU Accession Countries) in 2004, the countries in Eastern Europe and the Baltic States, and other countries of the former Soviet Union (FSU). ${ }^{27}$

These results are presented in Table 5. For purposes of comparison, the results from the basic equation for each sample country are reproduced in column 1 . The coefficient on lagged private savings is positive and statistically significant for all three country groups. The value varies from a low of 0.466 in the EU Accession countries to a high of 0.616 in the FSU indicating the presence of a large degree of persistence in these countries. Although there is no major difference among the other regression results for the three groups, a number of intriguing nuances in the pattern of savings in the three groups are evident. The coefficient on public savings is negative and statistically significant in all three groups, indicating that the private sector in these countries internalize government budget constraints. Notably, the short-run (long-run) magnitude of this effect is -0.275 ($0.515)$ and $-0.214(-0.41)$ in the Accession countries and Eastern European countries, respectively. This is far below the one-to-one relationship suggested by the simple Ricardian equivalence doctrine. On the other hand, the short- and long-run coefficients for the FSU countries are -0.378 and -0.984 , respectively. Hence, we cannot reject the Ricardian equivalence for these countries over the long run. The coefficient is very close to negative unity, which suggests private dissaving almost completely offsets government savings. The total gross savings in these countries is thus largely insensitive to the savings stance of the government. This may be due to the large budget deficits of many FSU countries.

The absolute value of coefficients for per capita GDP and monetization variables are much higher in the FSU countries than in the other two groups, indicating that private savings in the former Soviet Union countries are more sensitive to changes with respect to these two variables. The monetization variable has important policy implications in terms of prioritizing financial reforms in these countries. Countries with a relatively more developed financial system tend to generate a lower level of private savings. In other words, the availability of more credit instruments tends to raise the consumption level of

\footnotetext{
${ }^{27}$ Although the division is arbitrary and the countries within the three groups are heterogeneous, it seems to be a natural choice for a number of reasons. First, economic decline in the Eastern European and Baltic countries (the EU Accession countries form a subset of this group) in the early 1990s was, on average, less profound and persistent than that in the FSU. Second, in contrast to the FSU, most of the countries in the other two groups already had at least some elements of the market economy (e.g. private sector) before transition. Third, social safety nets in the Eastern European and Baltic countries during the sample period have been much stronger than in other FSU states. See Ivaschenko (2002).
} 
the consumers. This finding supports the UN (2001) view that any further catching up in these variables (considering that average per capita income level and monetization in the FSU are below those in the other two groups) might be expected to produce an even faster rate of catching up in private savings.

The behavior of the variables of interest - permanent and temporary components of terms of trade shocks, its variability and the dummy variable measuring asymmetric shocks - show some differences. All variables are positive and statistically significant. However, the magnitude of each variable is smaller in the FSU than in the other two country groupings. This seems counter-intuitive given that the trade of FSU countries is more dependent on primary commodities. Terms of trade shocks should have a larger impact on private savings in these countries.

\section{$7 \quad$ Conclusions}

Using data from twenty-one transition economies, this paper analyzed the impact of asymmetric terms of trade shocks on private savings. The paper began with a discussion of modeling the response of savings to both permanent and temporary shocks to the terms of trade. Economic agents in the transition economies are subject to tight credit constraints that are more pronounced in a bad state of nature. Thus, adverse shocks to commodity prices in the world market force economic agents to reduce savings by a larger amount than they would have otherwise. Conversely, they save more during good times. If households internalize the likelihood of facing binding borrowing constraints during bad times, they may also lower their consumption and save more during good times.

A number of conclusions can be derived from the estimation results. First, the private savings rate is highly persistent in transition economies. The effect of a change in one of the determinants of savings is fully realized only after several years. Long-term responses are approximately two times larger than the short-term responses.

Second, the private savings rate rises with real per capita income. Thus, policies that successfully stimulate development should indirectly raise the savings rate.

Third, financial reform has adversely affected private savings in transition economies. Larger financial depth, higher real interest rates, and interest rate margin changes failed to increase the private savings rate. The adverse effects were more pronounced in the FSU than in the Eastern European and Baltic states. Reform in the financial sector has stimulated consumption by relaxing domestic liquidity constraints, e.g. through increased access to bank credit, and thus reduce the propensity to save.

Fourth, macroeconomic instability, measured by inflation rate caused an increase in the precautionary motive to save. Similar behavior was evident when volatility of income was introduced in the model. The move from a cradle-to-grave system of state-guaranteed income to market-determined wages and the advent of high inflation and high unemployment (along with cuts in public benefits) raised income uncertainty and changed expected future income profiles in these countries [Denizer et al (2002)]. Our results show that households responded by increasing their precautionary savings.

Fifth, the empirical evidence indicated that the private sector internalized the government's budget constraint. The Ricardian equivalence was rejected for the Eastern European and Baltic states, but not for the FSU countries. In the latter group, public debt issues were macroeconomically indistinguishable from tax increases, thus changes in public savings were offset by an equal and opposite change in private savings. 
Sixth, a negative impact of an increase in the dependency rate on private savings was evident across all transition economies, thus supporting the traditional life-cycle hypothesis.

Finally, in contrast to the intertemporal choice literature, we found that the permanent component of the terms of trade had a significant positive impact on private savings. Transitory movements in the terms of trade also had a significant positive impact and a larger magnitude than the permanent component. This reflected the lack of access to foreign borrowing that many of the transition economies faced during the 1990s. Although the impact of terms of trade shocks was found to be asymmetric in the transition economies, the magnitude of impact appeared to be small. 
Table 1a:Merchandise trade of Eastern Europe, the Baltic and other former Soviet Union countries by region and by major product groups

\begin{tabular}{|c|c|c|c|}
\hline \multirow{2}{*}{ Total } & \multirow{2}{*}{$\begin{array}{l}\begin{array}{l}\text { Value of exports } \\
\text { (US\$ billion) }\end{array} \\
\mathbf{2 8 6}\end{array}$} & \multicolumn{2}{|c|}{ Percentage share of } \\
\hline & & 100.0 & 100.0 \\
\hline \multicolumn{4}{|l|}{ Region } \\
\hline North America & 12 & 4.1 & 2.9 \\
\hline Latin America & 6 & 2.1 & 1.1 \\
\hline Western Europe & 158 & 55.4 & 58.2 \\
\hline Transition Economies & 76 & 26.5 & 30.0 \\
\hline Africa & 3 & 1.1 & 0.4 \\
\hline Middle East & 8 & 2.7 & 0.7 \\
\hline Asia & 19 & 6.7 & 6.7 \\
\hline \multicolumn{4}{|l|}{ Product Group } \\
\hline Agricultural products & 25 & 8.7 & 10.5 \\
\hline Mining Products & 93 & 32.6 & 13.9 \\
\hline Manufactures & 161 & 56.4 & 74.7 \\
\hline
\end{tabular}

Source: UNCTAD

Table 1b: Annual percentage change in oil and non-oil commodity prices, 1981-1999

\begin{tabular}{lcccrr} 
Commodity Group & $1981-90$ & $1991-95$ & 1997 & 1998 & \multicolumn{1}{c}{1999} \\
\hline Non-oil Commodities & -2.3 & 4.1 & 2.2 & -15.7 & -6.3 \\
$\quad$ Agriculture & -3.2 & 5.6 & 2.5 & -16.2 & -5.2 \\
$\quad$ Metals and Minerals & 0.5 & 0.3 & 1.2 & -16.2 & -10.3 \\
$\quad$ Fertilizers & -2.5 & 0.7 & -0.1 & 2.0 & -5.2 \\
Petroleum & -4.7 & -5.6 & -6.2 & -31.8 & -8.2 \\
& & & & & \\
G-5 MUV $^{\mathrm{a}}$ & 3.3 & 3.6 & -5.1 & -3.9 & 1.3
\end{tabular}

Note: ${ }^{a}$ Manufactures Unit Value Index

Source: World Bank, Global Development Finance, 1999 
Table 2: Private savings and terms of trade: Alternative estimators
(1)
(2)
(3)

Estimator

OLS-CS

OLS-Static GMM-Systems

$\underline{\text { Regression }}$

Levels

Levels

Levels-Differences

Instruments

Difference-Levels

\begin{tabular}{|c|c|c|c|}
\hline PS(-1) & - & - & $\begin{array}{r}0.529 \\
(5.44)\end{array}$ \\
\hline RPCY & 0.521 & 0.424 & 0.179 \\
\hline & $(4.33)$ & $(3.76)$ & $(6.20)$ \\
\hline GRPCY & 0.202 & 0.248 & 0.287 \\
\hline & $(0.66)$ & $(1.25)$ & $(1.57)$ \\
\hline M2/GDP & 0.181 & -0.202 & -0.244 \\
\hline & (1.76) & $(2.63)$ & $(4.81)$ \\
\hline INF & -0.163 & -0.249 & 0.086 \\
\hline & (1.88) & $(2.50)$ & $(2.04)$ \\
\hline PUBSAV & -0.187 & -0.162 & -0.176 \\
\hline & $(2.90)$ & (3.11) & $(4.92)$ \\
\hline DEP & 0.230 & 0.072 & -0.303 \\
\hline & $(1.05)$ & $(0.61)$ & (1.99) \\
\hline PTOT & -0.051 & 0.021 & 0.076 \\
\hline & $(1.22)$ & $(0.74)$ & $(2.55)$ \\
\hline TTOT & 0.067 & 0.042 & 0.274 \\
\hline & $(2.05)$ & $(2.32)$ & $(3.18)$ \\
\hline VTOT & -0.041 & 0.007 & -0.202 \\
\hline & $(2.54)$ & $(1.97)$ & $(3.66)$ \\
\hline DUMMY & 0.001 & 0.001 & 0.011 \\
\hline & $(1.57)$ & (1.63) & $(4.15)$ \\
\hline No. of observations & 21 & 168 & 105 \\
\hline S.E.E. & 0.088 & 0.094 & 0.079 \\
\hline Wald Test & 0.000 & 0.000 & 0.000 \\
\hline Sargan Test & - & - & 0.288 \\
\hline Serial Correlation $\mathrm{T}$ & & & \\
\hline $1^{\text {st }}$ order & 0.002 & 0.090 & 0.048 \\
\hline $2^{\text {nd }}$ order & 0.004 & 0.091 & 0.536 \\
\hline
\end{tabular}

Note: Figures in parentheses are the absolute values of the t-statistics computed with heteroskedasticityconsistent standard errors. The p-values for the Wald Test, Sargan Test, and First- and Second-order Serial Correlation are given. 
Table 3: Private savings and terms of trade: Alternative determinants

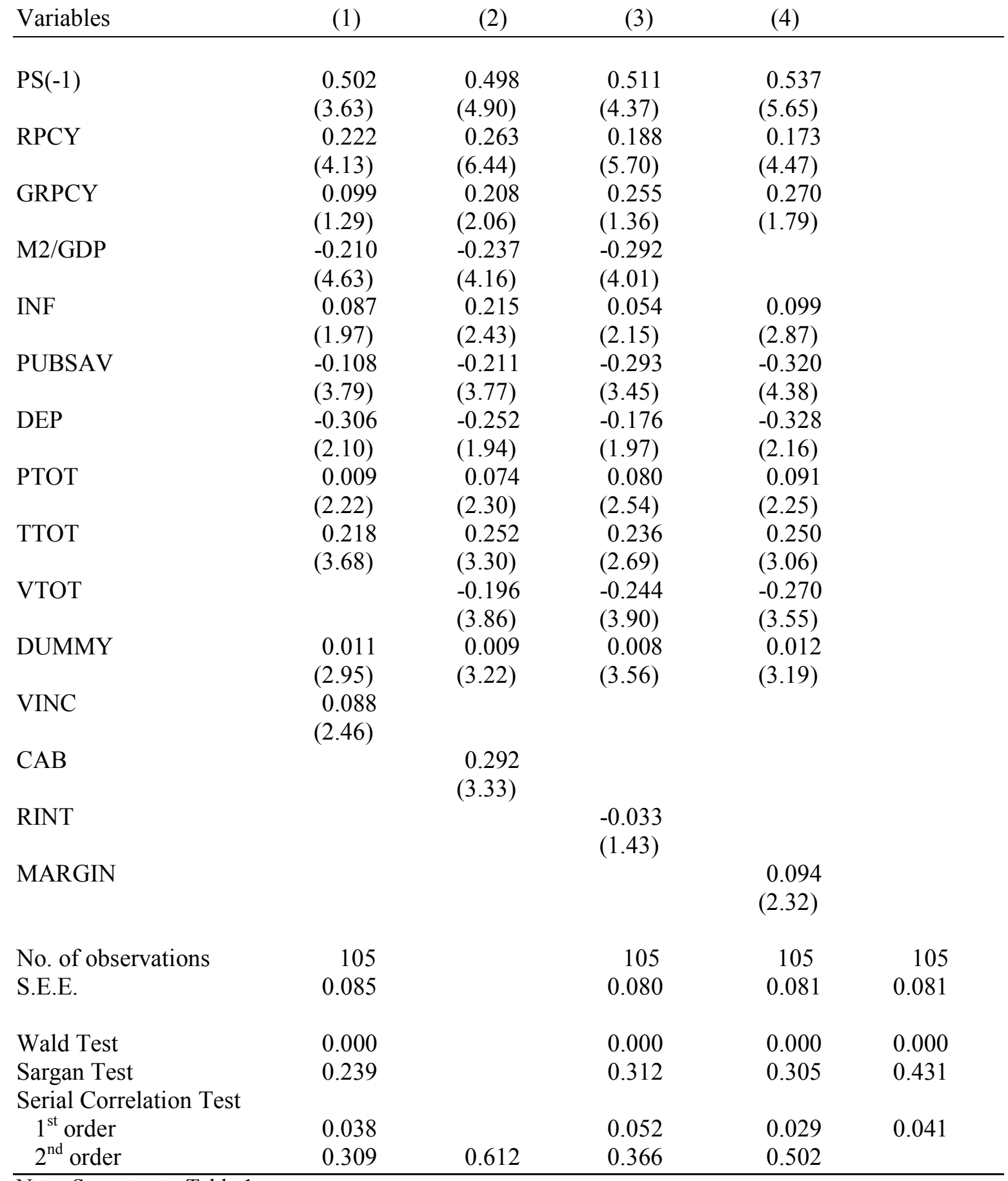

Note: See notes to Table 1. 
Table 4: Results from the extreme bound analysis

\begin{tabular}{lcclll} 
Variable & Bound & $\mathrm{b}_{\mathrm{i}}$ & $\begin{array}{l}\text { Sargan } \\
\text { Test }\end{array}$ & $\begin{array}{l}1^{\text {st }} \text { Order } \\
\text { Ser. Corr. }\end{array}$ & $\begin{array}{l}2^{\text {nd }} \text { Order } \\
\text { Ser. Corr. }\end{array}$ \\
\hline \multirow{3}{*}{ PS(-1) } & High & $0.662(4.16)$ & 0.19 & 0.00 & 0.16 \\
& Base & $0.614(4.59)$ & 0.20 & 0.00 & 0.23 \\
& Low & $0.575(4.13)$ & 0.25 & 0.00 & 0.34 \\
\multirow{2}{*}{ PTOT } & & & & & \\
& High & $0.092(2.18)$ & 0.46 & 0.04 & 0.55 \\
& Base & $0.063(2.09)$ & 0.42 & 0.05 & 0.51 \\
& Low & $0.041(2.17)$ & 0.39 & 0.04 & 0.33 \\
TTOT & High & $0.206(3.85)$ & 0.39 & 0.02 & 0.63 \\
& Base & $0.155(3.46)$ & 0.42 & 0.02 & 0.61 \\
& Low & $0.125(3.71)$ & 0.40 & 0.03 & 0.52 \\
\multirow{2}{*}{ VTOT } & & & & & \\
& High & $0.296(3.17)$ & 0.25 & 0.06 & 0.36 \\
& Base & $0.263(3.73)$ & 0.30 & 0.06 & 0.41 \\
& Low & $0.244(3.39)$ & 0.36 & 0.04 & 0.39
\end{tabular}

Note: The base ' $b$ ' is the estimated coefficient of the I-variable in equation (14) when the private savings rate is regressed on the I and $\mathrm{Z}$ variables using 2 SLS. The high ' $b$ ' is the estimated coefficient from the regression with the extreme high bound ( $b_{i}+$ two standard deviations); the low ' $b$ ' is the coefficient from the regression with the extreme lower bound. The figures in parentheses are absolute values of the t-statistics, which are computed with heteroskedasticity-consistent standard errors. 
Table 5: Private savings and terms of trade shocks: Alternative country groupings

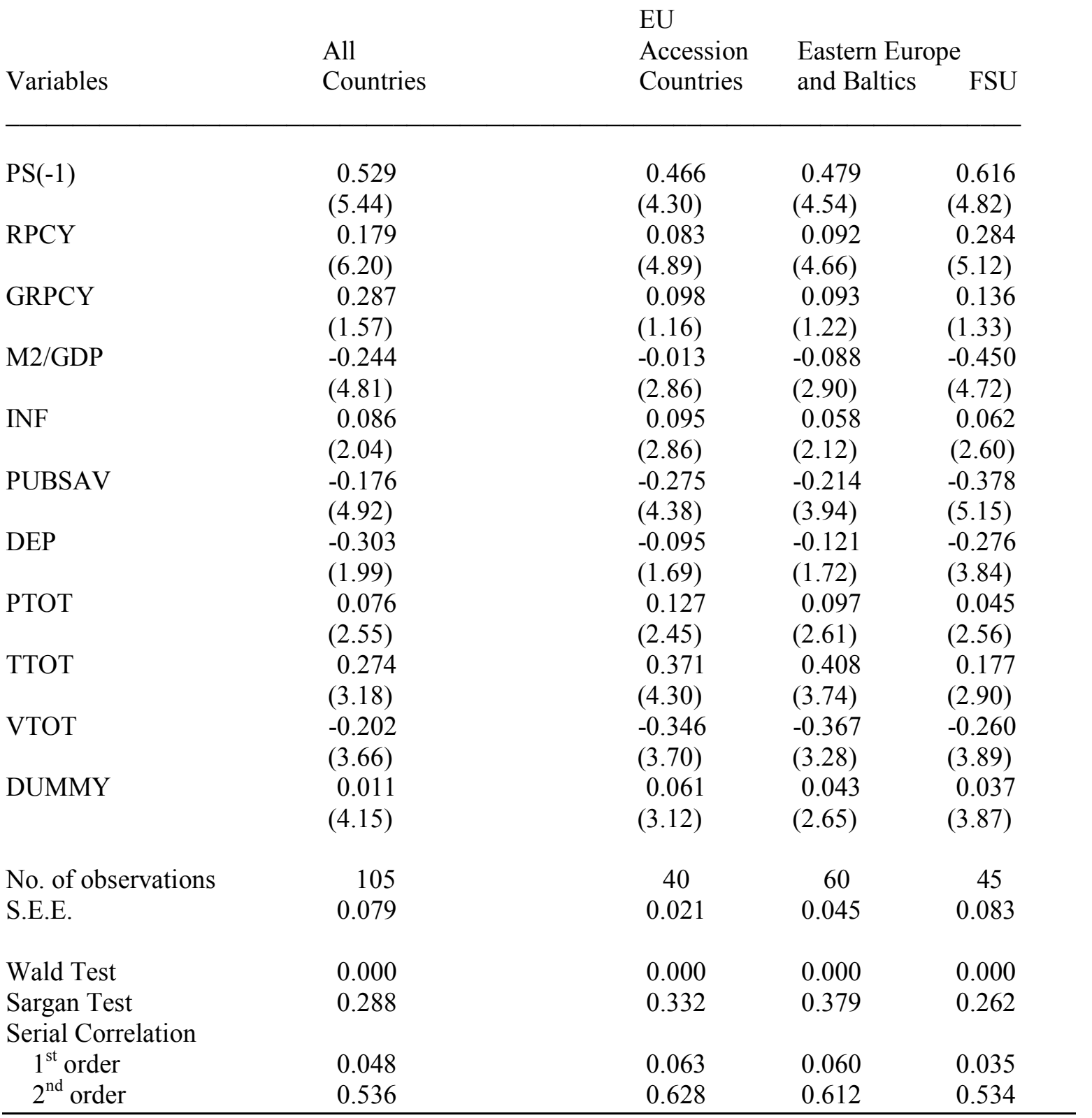

Note: Countries in the 'EU Accession Countries' category include the Czech Republic, Hungary, Poland, Slovakia, Slovenia, and the three Baltic states - Estonia, Latvia, and Lithuania. The 'Eastern Europe and Baltic States' group includes, in addition to accession candidates, Bulgaria, Croatia, Macedonia FYR, and Romania. The 'Former Soviet Union' (FSU) countries include Armenia, Azerbaijan, Belarus, Georgia, Kazakhstan, Moldova, the Russian Federation, Ukraine, and Uzbekistan. Data availability constrained the choice of countries, sample period, and variables. The p-value for the Wald Test, Sargan Test, and First- and Second-order Serial Correlation are given. 


\section{Appendix}

Table A1 Summary statistics of the variables

\begin{tabular}{lccccr} 
Variable & Mean & Median & Maximum & Minimum & Std. Dev. \\
\hline & & & & & \\
PS & 0.09 & 0.12 & 0.16 & 0.02 & 3.14 \\
RPCY & 116 & 178 & 267 & 72 & 39.37 \\
GRPCY & 0.38 & 2.40 & 17.60 & -21.20 & 5.62 \\
M2/GDP & 0.24 & 0.28 & 0.71 & 0.16 & 15.11 \\
INF & 69.80 & 44.11 & 103.00 & -5.70 & 146.37 \\
PUBSAV & 0.10 & 0.13 & 0.29 & -0.16 & 7.39 \\
DEP & 0.35 & 0.21 & 0.46 & 0.29 & 3.88 \\
PTOT & 0.446 & 0.321 & 0.676 & 0.210 & 8.35 \\
TTOT & 0.211 & 0.180 & 0.910 & 0.036 & 155.33 \\
VTOT & 0.054 & 0.076 & 2.09 & 0.003 & 38.16 \\
VINC & 0.078 & 0.062 & 0.395 & 0.039 & 43.62 \\
CAB & 0.066 & 0.091 & 0.262 & -0.035 & 59.36 \\
RINT & 0.053 & 0.049 & 0.161 & 0.021 & 13.88 \\
MARGIN & 22.25 & 11.30 & 400 & -21.40 & 43.65
\end{tabular}




\section{References}

Agenor, P., and J. Aizenman, (2002) "Savings and the Terms of Trade under Borrowing Constraints," Forthcoming, Journal of International Economics.

Agenor, P., J. McDermott, and E. Prasad, (2000) "Macroeconomic Fluctuations in Developing Countries: Some Stylized Facts," World Bank Economic Review, 14, May, 251-86.

Aizenman, J., (1998) "Buffer Stocks and Precautionary Savings with Loss Aversion," Journal of International Money and Finance, Vol. 17, December, 931-47.

Alessie, R., and A. Lusardi, (1997) "Consumption, Saving and Habit Formation," Economics Letters, 55, 103-108.

Anderson, T., and C. Hsiao, (1982) "Formulation and Estimation of Dynamic Models Using Panel Data," Journal of Econometrics, Vol. 18, 47-82.

Arellano, M. and S. Bond, (1991) "Some Tests of Specification for Panel Data: Monte Carlo Evidence and an Application to Employment Equations," Review of Economic Studies, Vol. 58, April, 277-97.

Arellano, M. and O. Bover, (1997) "Another Look at the Instrumental Variable Estimation of Error-Component Models," Journal of Econometrics, Vol. 68, 29-51.

Barro, R. and X. Sala-i-Martin, (1995) Economic Growth, New York, McGraw Hill.

Baxter, M. and M. Kouparitsas, (2000) "What Can Account for Fluctuations in the Terms of Trade?” December 2000, NBER Working Paper.

Bevan, D., P. Collier, and J. Gunning, (1993) "Trade Shocks in Developing Countries: Consequences and Policy Responses," European Economic Review, 37, April, 557-65.

Blanchard, O. and S. Fischer, (1989) Lectures on Macroeconomics, Cambridge, MA, MIT Press.

Blundell, R. and S. Bond, (1998) "Initial Conditions and Moment Restrictions in Dynamic Panel Data Models," Journal of Econometrics, 87, 115-43.

Bosworth, B., (1993) Savings and Investment in an Open Economy, Washington D.C., Brookings Institution.

Bowsher, C., (2002) "On Testing Overidentifying Restrictions in Dynamic Panel Data Models," Economics Letters, 77, 211-20.

Calderon, C., A. Chong, and N. Loayza, (1999) "Determinants of Current Account Deficits in Developing Countries," Policy Research Working Paper, World Bank, Washington, D.C.

Calderon, C., A. Chong, and L. Zanforlin, (2001) "Are African Current Account Deficits Different? Stylized Facts, Transitory Shocks, and Decomposition Analysis," IMF Working Paper WP/01/4, Washington, D.C.

Campos, N. and Y. Kinoshita, (2002) "Foreign Direct Investment as Technology Transferred: Some Panel Evidence from the Transition Economies," The Manchester School, 70, June, 398-419.

Cashin, P., J. McDermott, and A. Scott, (2002) "Booms and Slumps in World Commodity Prices," Journal of Development Economics, 69, 277-96. 
Cashin, P. and J. McDermott, (2002) "Terms of Trade Shocks and the Current Account: Evidence from Five Industrial Countries," Open Economies Review, Vol. 13, 219-35.

Chowdhury, A., (1993) "Does Exchange Rate Volatility Depress Trade Flows? Evidence from Error-Correction Models," The Review of Economics and Statistics, 75, November, 700-6.

Chowdhury, A., (2001) "The Impact of Financial Reform on Private Savings in Bangladesh," World Institute for Development Economics Research, Discussion Paper No. 2001/78, Helsinki.

Chowdhury, A., (2001) "External Debt and Growth in Developing Countries," World Institute for Development Economics Research, Discussion Paper No. 2001/95, Helsinki.

Corden, W., (1984) "Booming Sector and Dutch Disease Economics: Survey and Consolidation," Oxford Economic Papers, 36, 359-80.

Dayal-Gulati, A. and C. Thimann, (1997) "Saving in Southeast Asian and Latin America Compared: Searching for Policy Lessons," IMF Working Paper WP/97/110.

Deaton, A. and G. Laroque, (1992) "On the Behavior of Commodity Prices," Review of Economic Studies, 59, January, 1-23.

Denizer, C., H. Wolf, and Y. Ying, (2002) "Household Savings in the Transition," Journal of Comparative Economics, 30, 463-75.

Dornbusch, R., (1983) "Real Interest Rates, Home Goods, and Optimal External Borrowing,"Journal of Political Economy, Vol. 91, 141-53.

Edison, H., R. Levine, L. Ricci, and T. Sløk, (2002) "International Financial Integration and Economic Growth," Journal of International Money and Finance, 21, 749-76.

Edwards, S., (1989) "Temporary Terms of Trade Disturbances, the Real Exchange Rate and the Current Account," Economica, 56, 343-57.

Elbadawi, I. and F. Mwega, (1999) “Can Africa's Saving Collapse be Reverted?” in K. Schmidt-Hebbel and L. Sereven (eds.) The Economics of Saving and Growth, Cambridge, Cambridge University Press.

Fischer, S., (1993) "The Role of Macroeconomic Factors in Growth," Journal of Monetary Economics, 32, 485-512.

Hansen, L., (1982) "Large Sample Properties of Generalized Methods of Moments Estimators," Econometrica, 50, 1029-54.

Harberger, A., (1950) "Currency Depreciation, Income and the Balance of Trade," Journal of Political Economy, Vol. 53, February, 47-60.

Ivaschenko, O., (2002) "Growth and Inequality: Evidence from Transitional Economies," CESifo Working Paper No. 746, June.

Jappelli, T. and M. Pagano, (1995) "Savings, Growth, and Liquidity Constraints," Quarterly Journal of Economics, 109, 83-109.

Kent, C., (1997) "The Response of the Current Account to Terms of Trade Shocks: A Panel Data Study," Reserve Bank of Australia, Research Discussion Paper 9705.

King, R. and S. Rebelo, (1993) "Low Frequency Filtering and Real Business Cycles," Journal of Economic Dynamics and Control, 17, January, 207-31. 
Koivu, T., (2002) "Does Financial Sector Development Affect Economic Growth in Transition Economies?" mimeo, Institute for Transition Economies, Bank of Finland, Helsinki.

Konings, J., M. Rizov, and H. Vandenbussche, (2002) "Investment and Credit Constraints in Transition Economies: Micro Evidence from Poland, the Czech Republic, Bulgaria, and Romania,” LICOS Center for Transition Economies, Discussion Paper 112/2002, Belgium.

Lahiri, A., (1989) "Dynamics of Asian Savings: The Role of Growth and Age Structure," IMF Staff Papers, 36, 228-61.

Laursen, S. and L. Metzler, (1950) "Flexible Exchange Rates and the Theory of Employment," Review of Economics and Statistics, Vol. 32, November, 281-99.

Loayza, N., K. Schmidt-Hebbel, and L. Serven, (1999) "What Drives Private Saving Around the World?" in K. Schmidt-Hebbel and L. Serven (eds.), The Economics of Savings and Growth, Cambridge University Press, Cambridge.

Masson, P., T. Bayoumi, and H. Samiei, (1998) "International Evidence on the Determinants of Private Savings," The World Bank Economic Review, 12, 483-501.

Mendoza, E., (1997) "Terms of Trade Uncertainty and Economic Growth," Journal of Development Economics, 54, 323-56.

Obstfeld, M., (1982) "Aggregate Spending and the Terms of Trade: Is There a LaursenMetlzer Effect?” Quarterly Journal of Economics, Vol. 47, May, 251-70.

Ogaki, M., J. Ostry, and C. Reinhart, (1996) "Saving Behavior in Low- and MiddleIncome Developing Countries: A Comparison," IMF Staff Papers, Vol. 43, March, 3871.

Ostry, J., and C. Reinhart, (1992) "Private Saving and Terms of Trade Thocks," IMF Staff Papers, Vol. 39, September, 495-517.

Radulescu, R. and D. Barlow, (2002) "The Relationship Between Policies and Growth in Transition Countries," Economics of Transition, 10(3), 719-46.

Reinhart, C. and P. Wickham, (1994) "Commodity Prices: Cyclical Weakness or Secular Decline?” IMF Staff Papers, 41, February, 175-213.

Sachs, J., (1981) "The Current Account and Macroeconomic Adjustments in the 1970s," Brookings Papers on Economic Activity, 1, 201-68.

Spatafora, N. and A. Warner, (1999) "Macroeconomic and Sectoral Effects of Terms of Trade Shocks: The Experience of the Oil-Exporting Developing Countries," IMF Working Paper WP/99/134, October.

Svensson, L. and A. Razin, (1983) "The Terms of Trade and Current Account: The Harberger-Laursen-Metlzer Effect," Journal of Political Economy, Vol. 91, February, 97-125.

United Nations, (2001) Economic Survey of Europe, Economic Commission for Europe.

World Bank, (1999) Global Development Finance, Washington, D.C.

World Bank, (2000) Global Economic Prospects and the Developing Countries 2000, World Bank, Washington, D.C.

Zeldes, S., (1989) "Consumption and Liquidity Constraints: An Empirical Investigation," Journal of Political Economy, 97(2), April, 305- 


\section{BOFIT Discussion Papers}

2002 No 1 Ali M. Kutan and Niina Pautola-Mol: Integration of the Baltic States into the EU and Institutions of Fiscal Convergence

No 2 Juha-Pekka Niinimäki: Bank Panics in Transition Economies

No 3 Jouko Rautava: The role of oil prices and the real exchange rate in Russia's economy

No 4 Marketta Järvinen: Exchange rate regimes and nominal convergence in the CEECs

No 5 Axel Brüggemann and Thomas Linne: Are the Central and Eastern European transition countries still vulnerable to a financial crisis? Results from the signals approach

No 6 Balázs Égert: Investigating the Balassa-Samuelson hypothesis in transition: Do we understand what we see?

No 7 Maurizio M. Habib: Financial contagion, interest rates and the role of the exchange rate as shock absorber in Central and Eastern Europe

No 8 Christoph Fischer: Real currency appreciation in accession countries: Balassa-Samuelson and investment demand

No 9 John Bonin and Paul Wachtel: Financial sector development in transition economies. Lessons from the first decade

No 10 Juhani Laurila: Transition in FSU and sub-Saharan countries: The role of institutions

No 11 Antje Hildebrant: Too many to fail? Inter-enterprise arrears in transition economies

No 12 Alexander Muravyev: Federal state shareholdings in Russian companies: Origin, forms and consequences for enterprise performance

No 13 Jian-Guang Shen: Democracy and growth: An alternative empirical approach

No 14 Tuuli Koivu: Do efficient banking sectors accelerate economic growth in transition countries

No 15 Byung-Yeon Kim and Iikka Korhonen: Equilibrium exchange rates in transition countries: Evidence from dynamic heterogeneous panel models

No 16 Monika Blaszkiewicz, Jerzy Konieczny, Anna Myslinska, Artur Radziwil and Przemyslaw Wozniak: Some benefits of reducing inflation in transition economies

2003 No 1 Karsten Staehr: Reforms and economic growth in transition economies: Complementarity, sequencing and speed

No 2 Eugene Nivorozhkin: The dynamics of capital structure in transition economies

No 3 Abdur R. Chowdhury: Do asymmetric terms of trade shocks affect private savings in a transition economy? 


\section{BOFIT Discussion Papers}

ISBN 951-686-854-1 (print)

ISSN 1456-4564 (print)

ISBN 951-686-855-X (online)

ISSN 1456-5889 (online)

Editor-in-Chief likka Korhonen

Bank of Finland

Institute for Economies in Transition BOFIT

PO Box 160

FIN-00101 Helsinki

Phone: +358 91832268

Fax: +358 91832294

bofit@bof.fi

www.bof.fi/bofit 